\title{
DUALITIES IN ARCHITECTURAL TRAINING: THE ARCHITECTURE SCHOOL OF VALENCIA (1968-1975)
}

\author{
Débora Domingo-Calabuig ic \\ Universitat Politècnica de València (Spain) \\ dedoca@pra.upv.es
}

Received December 2017

Accepted March 2018

\section{Abstract}

The school of Valencia was a singular case study in the architectural training in Spain towards the end of the 60s. Like in Madrid, Barcelona, and Seville, the school also participated in the bustling political and social context, but while in these schools the curriculum of 1964 was extended until 1975, in Valencia the creation of the Instituto Politécnico Superior was the opportunity to launch an experimental curriculum introducing notable changes. Beginning in 1969, the new architecture students of Valencia shared a classroom and subjects' contents with students from 3 other degrees (Industrial Engineering, Civil Engineering, and Agricultural Engineering) and underwent continuous evaluations following a semester calendar. The architecture school of Valencia thus became a dual organism since the previous plan coexisted with the new one, but each was taught in different venues, isolated from one another. This work puts in parallel both curricula, both university environments and the teaching practices received by both group of students and tries to reconstruct the first years of history of the architecture school of Valencia thanks to testimonies and the few existing documentary sources. In addition, a critical assessment of the results is developed which is compared to the recent reflections and changes that have been occurring in the teaching of architecture.

Keywords - Architectural training, Architecture school of Valencia, Post-1968 architectural education, Architectural pedagogies.

\section{University Context: the Architecture Schools Towards 1968}

In the 60s, Higher education in Europe experienced a strong development as with housing and tourism issues. In England, France, Italy or Germany, the figures grew exponentially as the university changed its elitist image to that of a center opening its doors to all (Canella, 1968, Gibney, 2013). However, to this developmental vision in educational matters, a non-conformity movement put the institutions and their conductive roles in question. The social wave that emerged in France in 1968 represented a revolution that encompassed politics, culture, workers' demands... but also, and to a large extent, a change of attitude towards higher education training. This moment analysis made clear the sclerosis of the institutions and the "social marginalization" derived from the massification in the classrooms.

Architectural training did not escape the 1968 trigger, and the confronting positions with the "established power" manifested in different ways. Beatriz Colomina's "Radical Pedagogies" compiles the teaching practices which globally emerged claiming an adaptation to the architecture's new times, while Alan Powers (2015) talks about the introduction of the post-modern thinking, and the emphasis of graphics and anti-architectural strategies which, in the British context, produced the illusion of a great change -not actually achieved-. Towards the end of the $60 \mathrm{~s}$, experimentation on the architectural teaching had to do with its growing social consideration 
and with the urgent needs arising from the economic recession of the 70s (Doucet, 2017). As a matter of fact, L'Architecture d'Aujourd'bui published a monographic dossier in 1969, where the diversity of documentary sources supported a single message: the crisis of the architectural pedagogy (Figure 1).

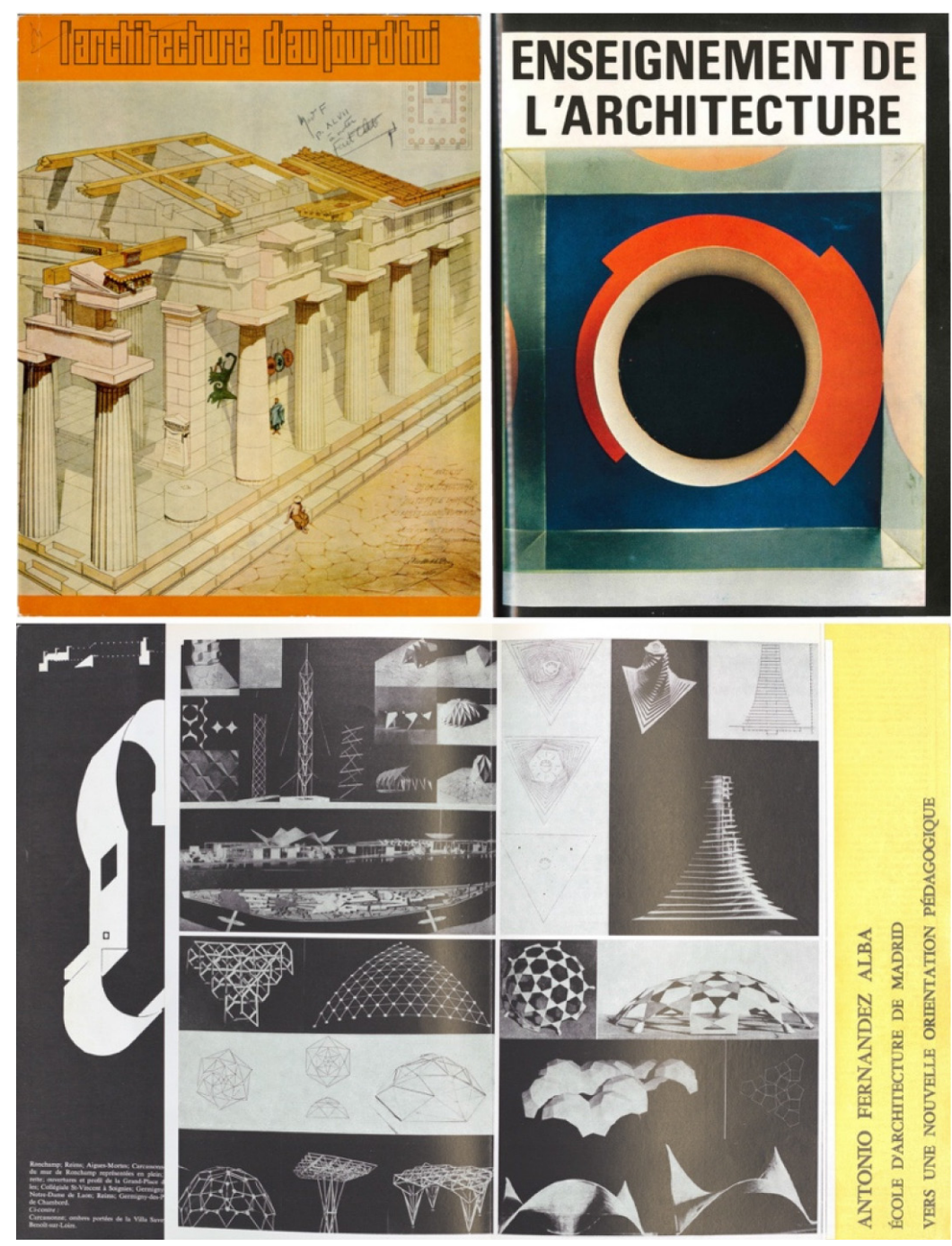

Figure 1. L'Architecture d'Aujourd'bui, 143 (1969) "L'enseignement de l'architecture"

At that time, there were three architecture schools in Spain: the one in Madrid in the Ciudad Universitaria, and one in Barcelona recently re-located to Avenida de la Diagonal in 1961, and the new school in Seville, still in its provisional headquarters. The university environment was then a hotbed if we look at some contextual conditions. During the dictatorship, positions such as provosts and deans were a government decision which helped maintain control in the institutions. However, the number of students in the classrooms increased progressively, and this overcrowding led to the hiring of new instructors precarious and non-permanent positions - thus allowing the entry into the universities of professionals not linked to the system's framework. The academic authorities and the regime's political police blocked more and more assiduously assemblies and any type of meeting prohibited by the law (Galcerán Huguet, 2008). The facts chronology reveals how political events were intertwined with pedagogical reflections, producing changes of attitudes among their protagonists.

According to Antón Capitel's words (González-Capitel, 2013), in the school of Madrid, 1968-1969 was the year known as "the year of the war". Javier Carvajal is generally recognized as the Head Professor who brought modernization to the education thanks to the introduction of young and energetic instructors -among others, Antonio Fernández Alba and Daniel Fullaondo-. In any case, the questions regarding pedagogics approaches were motives for constant strikes. The Nueva Forma review counted at that time 
with the tireless collaboration of José María Gómez-Santander (1968a), who wrote several chronicles advocating a reform in education or evaluating the new course of "Elements of Architectural Composition". Taught by Fernández Alba, this second-year subject was very much inspired by the School of Ulm (Gómez-Santander, 1968b). The last Gómez Santander's publication, entitled "Architecture School of Madrid. In the manner of goodbye" (Escuela de Arquitectura de Madrid. A la manera de adiós) should be highlighted as he voiced problems still in force today and added to a Carvajal's motto: "During my school time, I was just informed, but not trained" (Figure 2).

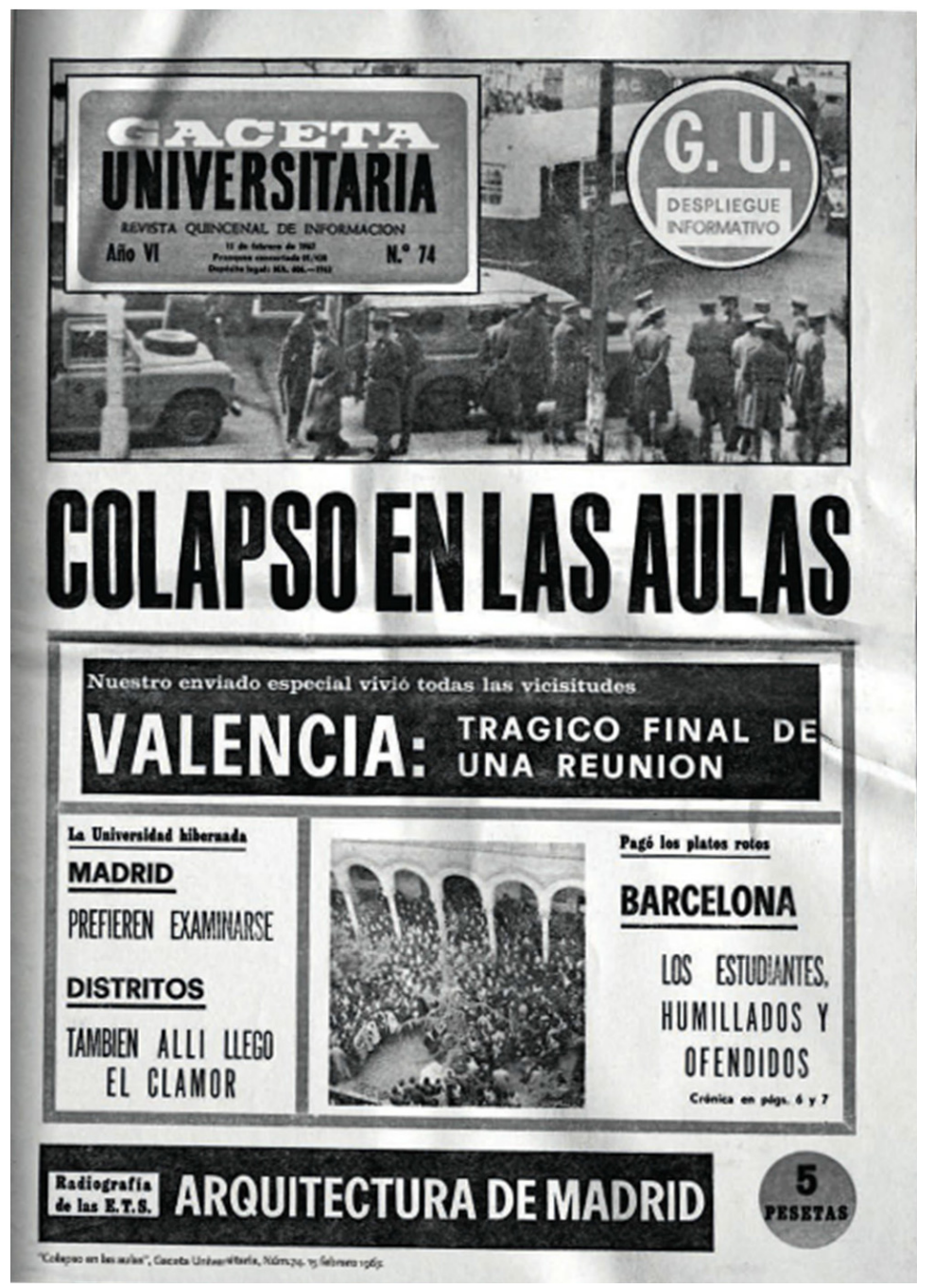

Figure 2. Gaceta Universitaria (February 1967)

In the architecture school of Barcelona, there were also neutralized students' assemblies, school's evictions and detentions for contempt of authority between 1966 and 1973. In this case, the Cuadernos de Arquitectura y Urbanismo review, through its section "News from the school of Barcelona" (Noticia de la Escuela de Barcelona), helps to understand the facts. The relationship between the content of the teaching and the real professional practices was the starting point of heated debates that resulted in strikes, resignations and also the transfer of teaching to an alternative location since it was impossible to complete the 1971-1972 academic year. There was also an unusual change of deans who only lasted one year in office: Manuel de Solà-Morales (1968-1969) first, and then Javier Carvajal (1972-1973) appointed DirectorCommissioner from the central government in Madrid, whose role did not leave positive chronicles in the Barcelona environment. 


\section{Architectural Pedagogies: European Breezes}

From a curricular point of view, the architectural teaching in Spain attended to a tradition of broad and diverse disciplines, reserved for a small student body which was capable of withstanding long-term studies. The curricula of the late nineteenth century of the schools of Madrid and Barcelona had an entrance exam, one or two preparatory courses (Algebra, Arithmetic, Geometry, Rectilinear Trigonometry, Physics and Chemistry...), and a four to six-year degree (Mechanics, History of fine arts, Stereotomy, Legal Architecture, Architectural composition studies, Optics, Hydraulics...) (García Gener, 2016). It was training aimed at an elite profession. A century and a half later, this situation was somewhat different: the entrance examination was abolished in 1956 and the 1964 curriculum did not contemplate the initiation course. The architectural training was carried out in 5 years, followed by the Final Career Project.

However, the pedagogical model had not changed substantially, and the reality of the classrooms corresponded to the usual methods: the theoretical subjects were taught through lectures and were evaluated with partial and final exams, and in the graphic courses students used to work while waiting for the professors' instructions who would then harshly evaluate their results. Still, in October 1968, the "Analysis of Architectural Forms" first-year subject continued entrenched in the old methods of the "ink-water copier", not being overcome by more than 10-13\% of the students (Gómez-Santander, 1971). This situation turned the subject into a kind of camouflaged entrance exam since the students took years to overcome it and could not, therefore, enroll in higher levels subjects. According to the complete report on the situation of the schools of Madrid and Barcelona published by Correa (1965), the main problem was the increasing number of students and the scarce adaptation to this situation of teaching methods. The ways which had worked for small groups no longer made sense with saturated classrooms.

The first pedagogical renewal debates were documented in the Arquitectura review between 1959 and 1964. Víctor d'Ors, then dean of the school of Madrid, published a lecture entitled "The architecture, the teaching, and the teaching of architecture" (La arquitectura, la enseñanza y la enseñanza de la arquitectura) in which he extensively justified an architect's profile "with a broad totalitarian and totalizing vision of the different techniques, arts and crafts which intervene in the habitable continents formation since he has to be the coordinator of all of them". He proposed an architect's training based on three cycles, in keeping with the stages of education which addressed a first academic phase ("architect's apprentices", learning of the arts), a second in-class part ("students of architecture", architect-edifying apprenticeship), and a third period of practices ("architects" assistants", learning a specialization). Oriol Bohigas soon reproached him in an open letter that his architect's vision was obsolete as he was not considering the architect as a "political man" whose professional problems would not be solved until assuming "a new pedagogy based in a new sociological sense".

As in a continuous conversation, and mentioning the previous writings, Roberto Puig published in 1964 two articles entitled "Other ideas for a new planning of architectural teaching in Spain" (Otras ideas para una nueva planificación de la enseñanza de la arquitectura en España). In the first, he longed for a dialogue between the university and the State, with real expressions freedom, shifting the focus from teaching (professor) to learning (student), calling for mobility and internationalization of professors, and even relating the teaching experiences with the suitability (or not) of the physical layout of the university buildings. In the second article, it is the concept of experience that takes the leading role. The author demanded active learning for the student: touching, moulding, assembling and dismantling... through the model (as teaching material), the drawing (as a tool and not as a purpose), and the sculpture, ceramics and other decorative arts. According to this learning based on experimental practice and inspired by the Bauhaus methodologies, Roberto Puig also proposed the students to face the architectural process linked to the real building. The Ministry of Housing could offer commissions to the architecture school that would be developed by professors and students. Thus, the professors would maintain contact with the professional world, without isolating themselves in their academic world. Furthermore, the students' group would be vertical, that is, including students of several levels which would help one another. All the subjects would be taught according to two units, one theoretical and one practical, where the latter would be integrated into a works site. 
The focus on Europe intensified with the two international conferences focused on the architectural training, which Spanish magazines had in their sights. The International Union of Architecture Students met in Stockholm in August 1965 to discuss their role in teaching. A month before, the International Union of Architects had dedicated its eighth congress to the architect's training in Paris. In both debates, the active participation of the student in the configuration of their own learning was claimed (Kalpakci, Radical Pedagogies). The professional variety of the architect's profile and the need to open the profession to the growing building demand focused the discussions led by Tomás Maldonado, dean of the school of Ulm (Architectural Design, 4/1965, Le Carré Bleu, 4/1965) (Figure 3).
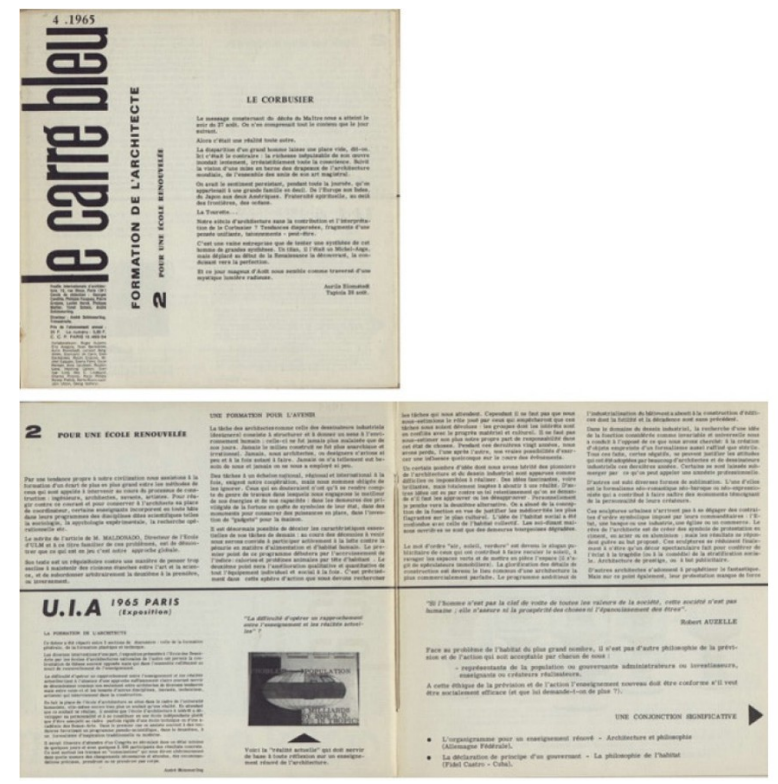
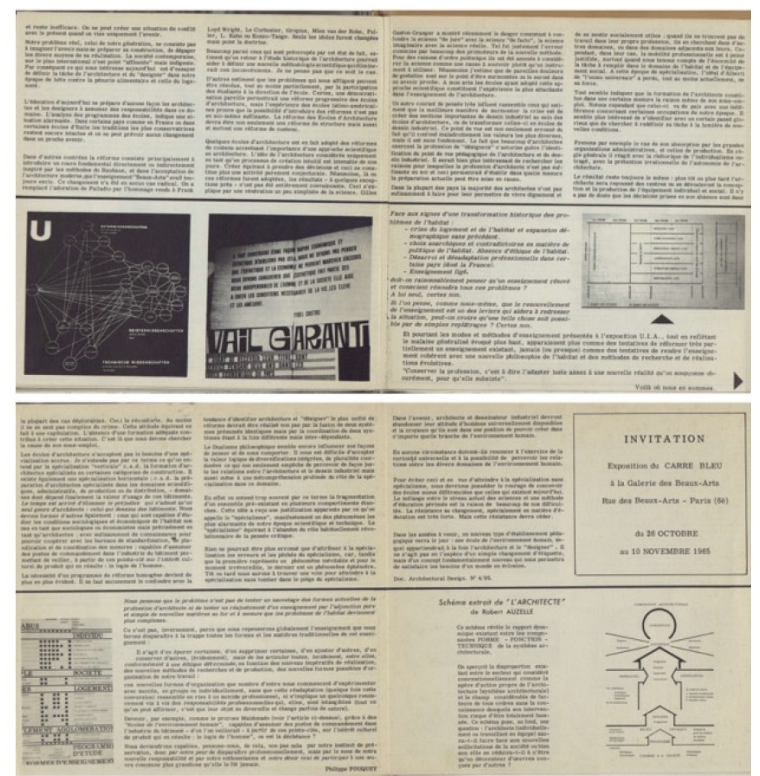

Figure 3. Le Carré Bleu (4/1965)

\section{Valencia: The Birth of a School and its Splitting}

The architecture school of Valencia was born as a "delegated school" of Barcelona, only for the first course, in 1965. During the 1966-1967 academic year, more than 300 students went to the so-called "Palacio de la Exposición" at Plaza de Galicia to attend a course which continuity was not guaranteed in that center. Finally, with the publication of "Law 5/1968, June 6 (Decreto Ley 5/1968), on urgent measures for university restructuring", new universities were created in Madrid, Barcelona and Bilbao, as well as the Instituto Politécnico Superior (IPS) in Barcelona and Valencia. With the subsequent "Law 2731/1968, October 24 (Decreto 2731/1968), on the organization of the IPS", the Schools of Architecture, of Civil Engineers, and of Industrial Engineers, were given the green light, and the already existing School of Agricultural Engineers of Valencia was integrated into the IPS. As a result of this, in 1968-1969, the teachings of the first, second and third courses of architecture were implemented, and the current curriculum was that of 1964.

However, less than a year later, the history of the Valencia school became a peculiar case study. A regulation dated September 16, 1969 (Orden de 16 de septiembre de 1969), approved, for all schools that made up the IPS of Valencia, an adaptation of the 1964 curriculum which made the first four semesters common to all the training degrees. The proposal was justified as a "new experience" and, certainly, drastic changes arose (Figure 4). 


\begin{tabular}{|c|c|c|c|c|}
\hline \multicolumn{5}{|l|}{ ARQUITECTURA } \\
\hline \multicolumn{3}{|l|}{ PLAN DE ESTUDIOS 1964} & \multicolumn{2}{|c|}{$\begin{array}{l}\text { PLAN DE ESTUDIOS } 1964 \text { - ADAPTACIÓN SEMESTRAL EN EL IPS } \\
\text { VALENCIA }\end{array}$} \\
\hline PRIMER CURSO & & & SEMESTRE 1 & SEMESTRE 2 \\
\hline Algebra lineal & & & Algebra lineal & Química (A) \\
\hline Cálculo infinitesimal & & & Cálculo infinitesimal (A) & Cálculo infinitesimal (B) \\
\hline Fisica & & & Fisica (A) & Fisica (B) \\
\hline Dibujo técnico & & & Dibujo técnico (A) & Dibujo técnico (B) \\
\hline Anáisis de formas & & & Metodología Aplicada & Dibujo de Formas \\
\hline \multirow[t]{6}{*}{ Geometria descriptiva } & & & & Geologia \\
\hline & & & Optativas & Optativas \\
\hline & & & Filosofia & Ética \\
\hline & & & Historia de la Civilización & Teoría de la Expresión \\
\hline & & & Inglés & Historia del Arte \\
\hline & & & & Inglés \\
\hline SEGUNDO CURSO & & & SEMESTRE 3 & SEMESTRE 4 \\
\hline Elementos de Composición & & & Ampliación de Matemáticas (A) & Ampliación de Maternáticas (B) \\
\hline Ampliación de Matemáticas & & & Ampliación de Fisica (A) & Ampliación de Fisica (B) \\
\hline Ampliación de Fisica & & & Análisis de Formas Arquitectónicas & Elementos de Composición (A) \\
\hline Historia del Arte & & & Conocimiento de Materiales & Historia del Arte \\
\hline Construcción I & & & Geometria Descriptiva (A) & Geometría Descriptiva \\
\hline Introducción a la Urbanistica & & & Optativas & Construcción I \\
\hline Economía & & & Biología & Resistencia de Materiales \\
\hline \multirow[t]{3}{*}{ Inglés | } & & & Estética & Matemáticas Técnicas Superiores \\
\hline & & & Estructura Económica Española & \\
\hline & & & Inglés & \\
\hline TERCER CURSO & & & SEMESTRE 5 & SEMESTRE 6 \\
\hline Proyectos arquitectónicos I & & & Proyectos arquitectónicos I (A) & Proyectos arquitectónicos I (B) \\
\hline Estética y Composición I & & & Estética y Composición I (A) & Estética y Composición I (B) \\
\hline Construcción II & & & Construcción II (A) & Construcción II (B) \\
\hline Cálculo de estructuras | & & & Cálculo de estructuras I (A) & Cálculo de estructuras I (B) \\
\hline Urbanística I & & & Introducción a la Urbanística & Urbanística I \\
\hline Instalaciones & & & Fontaneria y Saneamiento & Electrotecnia y Luminotecnia \\
\hline Electrotecnia y Luminotecnia & & & Economía & Historia de la Arquitectura (A) \\
\hline \multicolumn{5}{|l|}{ Inglés |I } \\
\hline CUARTO CURSO & Especialidad Urbanismo & Especialidad Edificación & SEMESTRE 7 & SEMESTRE 8 \\
\hline Proyectos arquitectónicos ॥ & Urbanistica II & Técnicas de Acondicionamiento & Proyectos arquitectónicos \|I (A) & Proyectos arquitectónicos ॥I (B) \\
\hline Construcción III & & Matemáticas técnicas superiores & Construcción III (A) & Construcción III (B) \\
\hline Cálculo de estructuras ॥ & & & Cálculo de estructuras ॥l (A) & Cálculo de estructuras II (B) \\
\hline Deontologiá, legislación y Valoraciones & & & Urbanistica II (A) & Urbanistica II (B) \\
\hline \multirow[t]{4}{*}{ Composición II } & & & Mecánica del Suelo (A) & Mecánica del Suelo (B) \\
\hline & & & Historia de la Arquitectura (B) & Jardineria \\
\hline & & & Técnicas de Acondicionamiento & Industrialización y Prefabricación \\
\hline & & & & Deontologia y Valoraciones \\
\hline QUINTO CURSO & Especialidad Urbanismo & Especialidad Edificación & SEMESTRE 9 & SEMESTRE 10 \\
\hline Proyectos arquitectónicos III & Practicas de Urbanismo & Proyectos de Estructuras & Proyectos arquitectónicos III (A) & Proyectos arquitectónicos III (B) \\
\hline Historia, Arquitectura y Urbanismo & Jardinería y Paisaje & Mecánica del Suelo & Estética (A) & Estética (B) \\
\hline Construcción IV & Instalaciones Urbanas & Industrialización y Prefabricación & Construcción IV (A) & Construcción IV (B) \\
\hline \multirow[t]{5}{*}{ Organización de Obras y Empresas } & Urbanistica III & Cálculo de estructuras III & Organización de Obras y Empresas & Legislación \\
\hline & & & Urbanistica III (A) & Urbanistica III (B) \\
\hline & & & Proyectos de Estructuras (A) & Proyectos de Estructuras (B) \\
\hline & & & Cálculo de estructuras III (A) & Cálculo de estructuras III (B) \\
\hline & & & Prácticas de Urbanismo & \\
\hline PROYECTO FINAL DE CARRERA & & & PROYECTO FINAL DE CARRERA & \\
\hline
\end{tabular}

Figure 4. Architecture School of Valencia: curricula of 1964 compared to its semester calendar adaptation 
Firstly, the academic period was divided into two semesters, a unit of temporary measure that shortened the subjects' syllabus. In addition, only official registration was allowed, and the students could not study autonomously and pass examinations at their own risk (quite a common way of training at that time): attendance was mandatory. To guarantee this last step, the teaching groups could not exceed 50 students in the theoretical subjects, and this figure had to be reduced to 25 in the practices. "The students" participation is strongly encouraged, stimulating their personal effort and promoting greater contact between professors and students', the regulation mentioned. Finally, the evaluation system was drastically modified: periodic tests should be established that would be completed with the final semester test. At the end of the semester, the whole period was assessed with success or failure. This qualification could mean having to complete the whole semester again. However, there should be a compensation system based on the "relative importance of the subjects". This imprecision on the subjects' "relevance" was a decision of a specific commission. Consequently, the extraordinary calls for examinations were stopped.

In relation to the knowledge areas, the curriculum produced substantial changes in the subjects. Semester elective subjects appeared, some of them of the optional, and others being compulsory for a specific degree. However, the proportional presence of the disciplines and their temporal distribution suffered the most from alteration. While in the annual curriculum, the architectural student had three annual subjects in graphics (Descriptive Geometry, Analysis of Architectural Forms, and Technical Drawing), in the new curriculum the training was reduced to three semesters -Technical Drawing A (first semester) and B (second semester) and Drawing of Architectural Forms in the second semester. That is, the teaching of drawing was reduced to $50 \%$ and content was designed for 4 joint degrees, with the consequent loss of specialization. In the same way, some unusual knowledge areas in the training of the architect made an appearance: chemistry was taught in the first two semesters.

From the current perspective, some proposed changes are not alien. It is worth recognizing the modernization that results from the technocratic government which characterized the last stage of the Franco dictatorship. The author of this experimental curriculum was José Luis Villar Palasí who is recognized for the educational reform undergone in Spain in 1970. It is surprising, however, that after the strategic changes outlined in a few pages of an official document, there is no development that ensures its start-up. The group size reduction required material and human resources, the subjects' contents shared among the 4 degrees needed a pedagogical reflection and agreement among the teaching staff.

As far as the teaching of architecture is concerned, the situation was one of complete duality as of that moment. Reticent to adopt the measures of the regulation, the 1964 annual curriculum co-existed with its semester adaptation, and the students of that generation seem to have lived in different periods and environments. The school management decided that only those students who had failed more than two first-year subjects would be asked to undertake the semester plan, and to these students from the next course would be added. In addition, the semester curriculum was taught in a different venue, in the new IPS building located on a site surrounded by fields on the northern outskirts of the city. The building, designed as a modular and constructive system responded to the flexibility required for a departmental teaching organization (Figure 5).

Thus, the semester curriculum was associated with the most unfavorable conditions possible: the students failing in their academic performance were asked to leave to attend the other school and the group was joined by the novice, while the veterans stayed in the center and close to other faculties. The students of the annual curriculum never had contact with the students of the semester one; there were no joint activities linking them. 


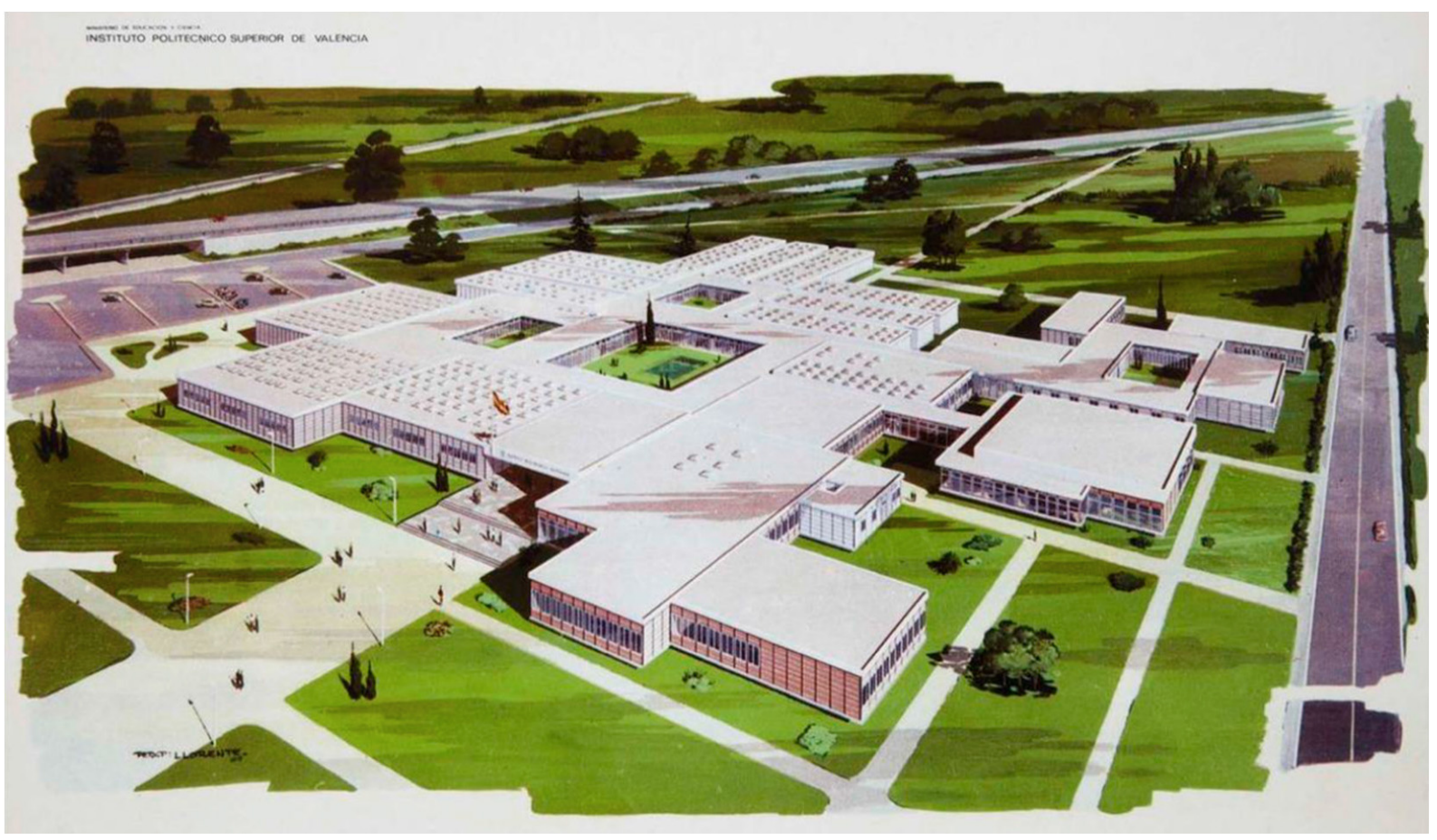

Figure 5. Instituto Politécnico Superior. Design drawing

\section{Student Environment and Teaching Practices}

The students from the old school remember an effervescent atmosphere, where political issues were continually mixed with pedagogical demands. For example, the visit of Minister Villar Palasí in December 1968 was answered with a general booing on the main stairs of the school, and the next day an academic strike was declared. The official press offered its own version of the news (Levante, December 10, 1968): "(...) Mr Villar Palasi visited the School of Architecture, which is settled in the former Palacio de la Exposición, and he met with a large group of student representatives (...)".

In spite of everything, the teaching practices were not affected by any renovation in this school. The professors, trained in the schools of Madrid and Barcelona, taught like their professors did and they seemed to question neither content nor learning practices. On the one hand, in subjects such as Algebra and Calculus, but also Construction, Structures or Mechanics of Soil, the student received lectures in a classroom, studied with notes and books on their own, and was examined at the end of the year. Students keep better or worse memories according to the clarity with which the professors explained the lessons and the proportionality between the contents taught and the knowledge needed to pass the evaluation.

In addition, in the first-year graphic subjects, learning was mostly based on communication between students and repeaters: it was almost about finding the formula or the right method to awaken the lack of interest from the teaching staff. In general, many mention professors as strict evaluators rather than good instructors. However, the continuous complaints regarding the drawing exercises caused some notable changes and students managed to update contents. Specifically, students refused to copy the sheets of Vignola's order over and over in the Technical Drawing course. When drawing outdoors, monuments and ornamental fountains were studied. The satiety was significant enough because the students managed to exclude the professors from the process and agreed on a mixed jury composed by professors and former students for the final tests. That year, the exam took place in the Labor University of Cheste (by Moreno-Barberá architect, built in 1965-1969), in the June session, and on the German School of Valencia (by Navarro-Alvargonzález, Trullenque-Sanjuán \& Rubió-Tudurí, built in 1959; 1961), in September. The students who were part of that jury report an evaluation system based on the exposure of the design panels on easels which were turned over if they did not pass, but above all, they recognize the updating of the architectural contents under study. 
Evidence of what the atmosphere was like in the old school can be deduced from the magazine Módulo 68, published by the Students Union of Architecture of Valencia. Its contents combine articles on the education and the training of the architect, with manifestations against the War of Vietnam and biographical notes of Che Guevara. Furthermore, detailed chronicles of the International Students of Architecture Conference (Stockholm, August 1965) are collected as well as the results of a survey made to architects and professors of the school of Valencia. The questions reflect the students' concern for the profession: Do you consider architecture as a technique, as an art or as a mixture of both? Do you think there is an industrialization of architecture? What should be the role of the architect for a specific society and culture like ours? Do you consider the architect as a witness or as an educator of society? Does the current training of the architect seem pedagogical?... (Figure 6).
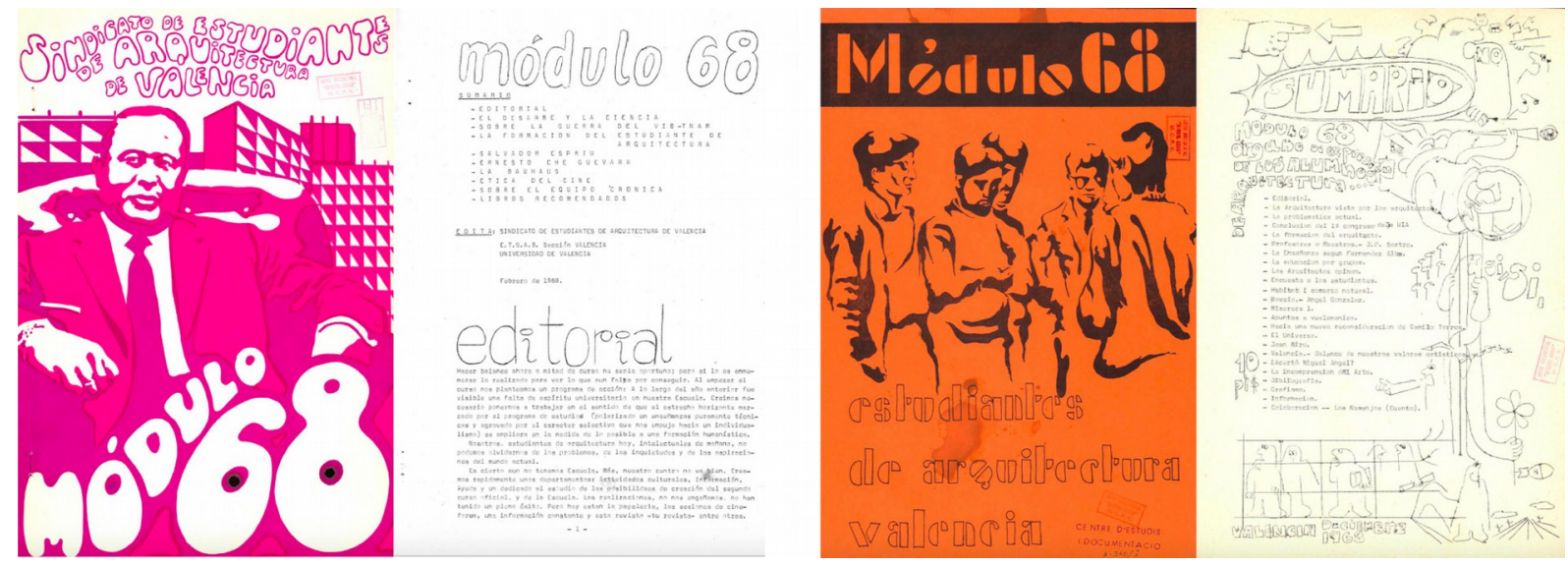

Figure 6. Módulo 68 (February 1968, December 1968)

The memories of the students of the new IPS building are alien to these events. They shared a classroom with future engineers, and hardly the graphic exercises were close to the discipline: "we drew screws and propellers of boats". Neither did they seem to understand the usefulness of a mathematics, physics or chemistry syllabus unrelated to the architectural discipline. They had exams every Monday, and this required a strong rhythm of study that prevented them from getting involved in other matters. The building was empty and there were no students of higher courses to ask for advice or with whom to share experiences. The presence in the classroom was controlled scrupulously as if they were at school. The pass rate was negligible, and word spread that it was pre-fixed, so strong competition developed between them. They knew of the political protests when their comrades ran to take refuge in the new building, fleeing from the police that ran through the faculties of the avenue of Blasco Ibáñez. The intentions of modernity and progress of the semester curriculum became a failure due to the lack of means, of understanding of the objectives, and of the willingness of entrepreneurship. Of all the sources consulted, no one (neither professors nor students) wield positive arguments for this pedagogical experience, which was deleted from the scene as soon as the legislation allowed it.

What happened then in the department of architectural design subjects? The same, in both curricula. The faculty staff moved from one venue to another to repeat their classes, without altering methods or content, although each student came from a different curriculum path, and group sizes varied substantially in number. A professor remembers how the same subject group had 110 students in the old school, compared to only 8 in the new IPS.

The institution was young, the faculty staff was being hired as the courses progressed, and the number of students was growing. Therefore, among the most veteran students the professors looked for assistants. Thus, last-years students used to assist professors in second/third-year subjects, and this way new reflections were introduced such as a series of lessons in "Elements of Architectural Composition" which were inspired by theories of the visual language of Tomás Maldonado in the school of Ulm. Furthermore, and since "Elements of Architectural Composition" was a second-year subject (and its contents did not include the architectural design yet), there were only 3 specific subjects to develop the architectural design 
learning, with a lot of weekly dedication. The students of "Architectural Design I" began with short exercise practices (telephone booth, the adaptation of a van as a home, medical consultation...) and ended up by designing consistent programs such a student residence (Figure 7). In the "Architectural Design II" course (4th year) students dealt with the housing design for the photographer of the well-known film Blow Up by Antonioni, or the interior equipment of passengers in a commercial airplane. The Final Degree Project had no teaching; After completing the 5th year, the student was provided with an assignment that had to be developed autonomously. The final evaluation depended on a large jury consisting of professors, and representatives of the Architects Association and local government.

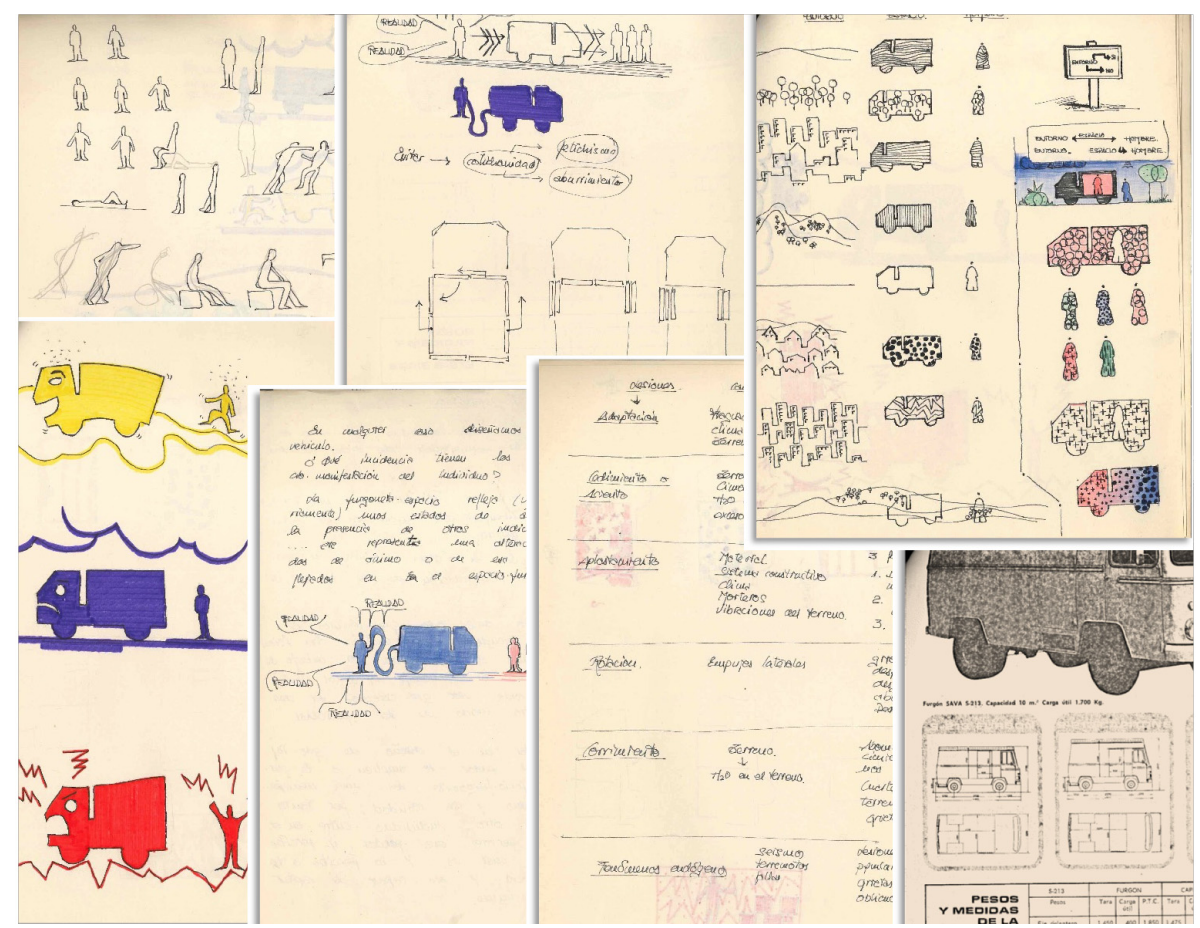

Figure 7. Student sketches for "Architectural Design I" (Student: Rafael Rivera-Herráez, circa 1970)

\section{A look from the Present}

One is tempted to make a parallel between the events of the architecture school of Valencia during the 10 years that follow 1968 and the latest changes in the curricula in Spain, confronting the written (legislation and regulations) with what happened (the reality in the classrooms). The curricula adapted to the European Higher Education Area, also known as the Bologna curricula, considered measures which sound familiar to those of that 1964 semester curriculum: continuous evaluation, biannual calendar, small groups... The main objective has similarities - accompanying the student continuously in their learning, advocating a cross-disciplinary approach - although the Bologna aspirations are of greater importance -education based on competencies, learning based on experience...-. Successes and failures (total or partial) can also be evidenced by shared arguments.

Any structural change in a teaching system must logically entail a reflection on the means for its development. This does not only mean economic and material issues, but also the communication, preparation and updating of human resources. In the first case, the relationship between pedagogy and the space for education must be demonstrated. The IPS building and the subsequent campus of the Universitat Politècnica de València were designed for a departmental organizational structure and specific teaching methodologies, but it seems that this reflection on the spatial needs has not been reviewed within the subsequent curricula. Secondly, and with respect to the teaching staff, one of the interviewees for this work (student of the 1964 annual plan, professor of the semester curriculum in the IPS and of all the other curricula that have occurred to date) regretted that the reflection on new learning methodologies and the necessary coordination between subjects were issues almost always solved with the personal initiatives and the individuals wills. 
Regarding the regular negative impressions, confusing follow-up and evaluation with presence control and over-evaluation is a constant and common mistake. Likewise, it seems that the look abroad is carried out without a true internationalization of resources and means.

Finally, two open reflections that feed the eternal debate about the architectural design learning are evident in this historical journey. One of them responds to the temporal moment, throughout the studies, in which the student must approach the experience of designing and the questions that relate this beginning with the maturity and the previous formation. The 1964 curricula were to have only 3 architectural design subjects and the student went from doing simple exercises to complete projects in a more limited temporal arc than the current one. Another question is the accompaniment to the learning of different levels students. The isolation that occurred when separating a few generations of others in the two schools of Valencia did note between the results. The architectural design learning shared between several levels has general acceptance among professors but little flexibility from the administrative instances, still nowadays.

\section{Acknowledgment}

This work makes use of documentary sources of the Arxiu de la Memoria d'Acció Cultural del Pais Valencià, located in the public library Pedro Ibarra de Elche, to whose staff I acknowledge their help and support in consulting the documents.

In addition, the reconstruction of the events which took place in the architecture school of Valencia would not have been possible without the testimonies of students and professors. Rafael Rivera Herráez, architect and professor of the Department of Urbanism and student of the 1975 promotion, has yielded the works and exercises that are shown, besides having generously fed the investigation with his memories. In the same way, I thank José María Lozano, Vicente Mas, Ignacio Bosch, Fernando Aranda, Josep Luis Ros, Carles Dolç, Alejandro Pons, Vicente González-Móstoles, and Rafael Tamarit, for the conversations I held with them.

\section{Declaration of Conflicting Interests}

The author declared no potential conflicts of interest with respect to the research, authorship, and/or publication of this article.

\section{Funding}

The author received no financial support for the research, authorship, and/or publication of this article.

\section{References}

Canella, G. (1968). Passé et avenir de l'anti-ville universitaire. L'Architecture d'aujourd'bui, 137, 17.

Correa, F. (1965). La Enseñanza de Arquitectura en España. Zodiac, 15, 179.

Decreto 2731/1968, de 24 de octubre, sobre organización del Instituto Politécnico Superior de Valencia. BOE, 11 de noviembre de 1968, 271, 13929. España.

Decreto Ley 5/1968, de 6 de junio, sobre medidas urgentes de reestructuración universitaria. BOE, 7 de junio de 1968, 137, 8254-8255. España.

Doucet, I. (2017). Learning in the "Real" World: Encounters with Radical Architectures (1960s-1970s). Journal of Educational Administration and History, 49(1), 7-21. https://doi.org/10.1080/00220620.2017.1252735

Galcerán Huguet, M. (2008). El mayo del 68 francés y su repercusión en España. Dossiers Feministes, 12, 77-98. 
García Gener, P. (2016). La docencia de la ETS AM en su contexto bistórico: 1844-2015. E.T.S. Arquitectura. Universidad Politécnica de Mardrid. http://oa.upm.es/39184/.

Gibney, E. (2013). Robbins: 50 Years Later. Times Higher Education. Available at: https://www.timeshighereducation.com/features/robbins-50-years-later/2008287.article

Gómez-Santander, J. M. (1968a). Escuela de Arquitectura de Madrid. En torno a una reforma de la enseñanza de la arquitectura. Nueva Forma: Arquitectura, Urbanismo, Diseño, Ambiente, Arte, 33, 139-140.

Gómez-Santander, J. M. (1968b). Escuela de Arquitectura de Madrid. En torno a la cátedra elementos de composición. Nueva Forma: Arquitectura, Urbanismo, Diseño, Ambiente, Arte, 34, 129-130.

Gómez-Santander, J. M. (1971). Escuela de Arquitectura de Madrid. A la manera de adiós. Nueva Forma: Arquitectura, Urbanismo, Diseño, Ambiente, Arte, 63, 26.

González-Capitel, A. (2013). Mis memorias de la escuela de arquitectura. Veredes. Available at: https://veredes.es/blog/mis-memorias-de-la-escuela-de-arquitectura-anton-capitel/

Orden de 16 de septiembre de 1969, por la que se dictan normas transitorias sobre matrícula en el Instituto Politécnico Superior de Valencia. BOE, 1 de octubre de 1969, 235, 15395-15396. España.

Powers, A. (2015). The Fiction of Architectural Education. Radical Pedagogies. Architectural Education and British Tradition. London: Royal Institute of British Architects.

Published by OmniaScience (www.omniascience.com)

Journal of Technology and Science Education, 2018 (www.jotse.org)

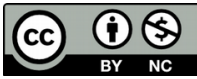

Article's contents are provided on an Attribution-Non Commercial 4.0 Creative commons International License. Readers are allowed to copy, distribute and communicate article's contents, provided the author's and JOTSE journal's names are included. It must not be used for commercial purposes. To see the complete licence contents, please visit https://creativecommons.org/licenses/by-nc/4.0/. 